\title{
Multihormonal Immunoreactivity Present in Two or More Cell Types
}

National Cancer Institute

\section{Source}

National Cancer Institute. Multihormonal Immunoreactivity Present in Two or More Cell

Types. NCl Thesaurus. Code C154503.

A finding indicating that neoplastic cells of two or more cell types have detectable immunoreactivity for different hormones in a tissue sample. 